BUDGETING : Journal of Business, Management and Accounting

Volume 1, Nomor 1, Desember 2019

e-ISSN: 2715-2480

p-ISSN: 2715-1913

DOI : https://doi.org/10.31539/budgeting.vli1.780

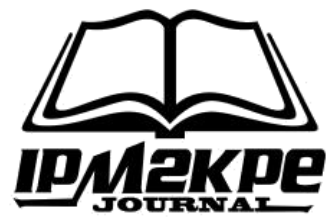

\title{
ANALISIS EFEKTIVITAS PERUSAHAAN DENGAN MODEL DU PONT SYSTEM
}

\author{
Bagja Pasca Ramadhan ${ }^{1}$, Acep Samsudin ${ }^{2}$, Dicky Jhoansyah $^{3}$ \\ Universitas Muhammadiyah Sukabumi ${ }^{1,2,3}$ \\ bagjaxiips@gmail.com ${ }^{1}$
}

\begin{abstract}
ABSTRAK
Penelitian ini bertujuan untuk mengetahui model $\mathrm{Du}$ Pont System dalam menganalisis efektivitas operasional perusahaan dalam menghasilkan laba pada PT. Gajah Tunggal Tbk. Penelitian ini mempergunakan teknik analisis deskriptif kuantitatif yang dipergunakan untuk menggambarkan dalam mengukur efektivitas yang dilakukan oleh perusahaan setelah melaksanakan perhitungan dengan angka-angka yang telah dimasukan dalam komponen-komponen atau rumus yang terdapat dalam model Du Pont System yaitu Rasio Profitabilitas yang terdiri dari Marjin Laba Bersih (Net Profit Margin) dan Pengembalian Atas Investasi (Return On Invesment), lalu Rasio Aktivitas yang terdiri dari Perputaran Total Aset (Total Asset Turnover). Simpulan, efektivitas perusahaan selama lima tahun tersebut dinilai kurang baik melihat penurunan yang terjadi pada beberapa aspek yang di teliti dapat mempengaruhi nilai akhir Du Pont System.
\end{abstract}

Kata Kunci: Efektivitas Perusahaan, Du Pont System

\begin{abstract}
This study aims to determine the Du Pont System model in analyzing the effectiveness of the company's operations in generating profits at PT. Gajah Tunggal Tbk. This study uses quantitative descriptive analysis techniques that are used to describe in measuring the effectiveness of the company after carrying out calculations with the figures that have been included in the components or formulas contained in the Du Pont System model that is the Profitability Ratio consisting of Net Profit Margins (Net Profit Margin) and Return on Investment (Return On Investment), then Activity Ratio which consists of Total Asset Turnover. Conclusion, the effectiveness of the company for five years is considered not good seeing the decline that occurred in several aspects that could affect the final value of the Du Pont System.
\end{abstract}

Keywords: Company Effectiveness, Du Pont System 


\section{PENDAHULUAN}

Dewasa ini persaingan industri semakin kompetitif atau bersaing antara perusahaan satu dengan perusahaan yang lainnya. Demi meningkatkan profit dan mendapatkan konsumen, perusahaan harus meningkatkan kualitas dari produk atau jasa yang di tawarkan agar merebut minat para konsumen atau merubah konsumen menjadi pelanggan. Salah satu industri yang bersaing dan sedang ramai saat ini adalah industri otomotif. Dilihat dari fakta yang terdapat di Badan Pusat Statistik, jumlah pengguna kendaraan bermotor di Indonesia saja pada tahun 2016 berjumlah kurang lebih 129 juta pengguna dan diprediksi bakal terus bertumbuh.

Industri otomotif merupakan salah satu pilar penting dalam industri sektor manufaktur di Indonesia, hal ini ditandai dengan banyaknya perusahaan-perusahaan manufaktur mobil yang bermunculan. Selain dari itu industri otomotif juga berperan penting dalam meningkatkan perekonomian di Indonesia karena selain memenuhi permintaan sarana transportasi, industri otomotif juga dapat membuka lapangan pekerjaan bagi masyrakat Indonesia. Dilansir dari GAIKINDO agar indsutri otomotif dapat berperan bagi kontribusi ekonomi Indonesia, pemerintah harus mendorong industri ekonomi dalam hal inovasi teknologi, menambah investasi, meningkatkan serapan tenaga kerja, serta menggandeng mitra lokal.

Salah satu perusahaan dalam industri otomotif adalah perusahaan manufaktur ban dan salah satu perusahaan manufaktur ban terbesar di Indonesia adalah PT Gajah Tunggal Tbk yang merupakan perusahaan sub sector otomotif yang memproduksi ban kendaraan di Indonesia yang terdaftar di BEI (Bursa Efek Indonesia). Gajah Tunggal Tbk merupakan perusahaan manufaktur yang memproduksi ban kendaraan yang didirikan pada tahun 1951 dan telah terdaftar di BEI (Bursa Efek Indonesia).

Dilihat dari penjelasan yang dilansir Badan Pusat Statistik tentang pengguna kendaraan di Indonesia di atas, produksi kendaraan mobil akan naik yang akan berimbas pada kenaikan penggunaan kendaraan bermobil di Indonesia. Dalam hal ini perusahaan manufaktur ban pun akan ikut merasakan dampak permintaan produknya karena dalam memproduksi mobil pasti dibutuhkan ban untuk melengkapi salah satu suku cadang dalam sebuah kendaraan. Karena permintaan produk yang maningkat maka dari itu perusahaan perlu memperhatikan aktivitas operasional perusahaanya dalam mengelola perusahaanya. Dalam mengelola aktivitas operasional nya perusahaan perlu 
memerhatikan aspek efektivitas agar perusahaan dapat memperoleh laba atau profit yang diinginkan perusahaan. Efektivitas yang di maksud adalah efektivitas dalam laba penjualan dan pengelolaan aktiva dalam menghasilkan laba suatu perusahaan.

Dalam menjalankan roda ekonomi perusahaan, perusahaan bertanggung jawab atas efektivitas dan efisiensi perusahan Pencapaian tujuan banyak digunakan dalam pengukuran keefektifan organisasi. Efektivitas diartikan sebagai pencapaian tujuan secara tepat dan dapat juga diartikan sebagai pengukuran keberhasilan dalam mencapai tujuan. Efisiensi dapat diartikan sebagai penggunaan sumber daya minimum demi mencapai hasil yang optimal. Dalam perusahaan apabila konsep efektivitas dan efisiensi tidak diperhatikan maka perusahaan akan menghadapi inefisiensi.

Dalam menilai efektivitas dalam suatu perusahaan diperlukan bahan yang dapat menggambarkan posisi keuangan perusahaan yaitu laporan keuangan (Lianto, 2013). Di dalam perusahaan tidak lepas dengan yang namanya laporan keuangan karena laporan keuangan dapat memberikan informasi kepada pihak manajemen perusahaan atau pemakai laporan keuangan bagaimana kondisi keuangan perusahaan dan laporan keuangan juga dapat menggambarkan kinerja keuangan dari suatu perusahaan sehingga perusahaan dapat merencanakan, meramalkan strategi dan membuat keputusan ekonomi perusahaan ke depannya agar lebih baik dan mendapatkan laba yang diinginkan. Laporan keuangan juga ditunjukan sebagai apa saja yang di lakukan manajemen dan bukti pertanggung jawaban manajemen atas pengelolaan suatu perusahaan dan biasanya ditunjukan pada setiap akhir periode.

Guna melihat dan menilai tingkat efektivitas operasional suatu perusahaan tidak hanya menggunakan kepekaan dan ketajaman para manajer secara kualitatif saja, tetapi harus menggunakan metode secara kuantitatif. Efektivitas suatu perusahaan dapat dinilai dengan salah satu metode pada analisis laporan keuangan yaitu dengan menganalisis Rasio Aktivitas dan Rasio Profitabilitas nya. Efektivitas yang di maksud adalah efektivitas dalam menghasilkan laba dari penjualan dan efektivitas dalam pengunaan aktiva perusahaan dalam memperoleh laba.

\section{KAJIAN TEORI}

\section{Laporan Keuangan}

Laporan keuangan disusun dengan maksud untuk menyediakan informasi keuangan suatu perusahaan kepada pihak-pihak yang berkepentingan sebagai bahan 
pertimbangan di dalam mengambil keputusan (Kasmir, 2012). Beberapa hal yang perlu diperhatikan dalam analisis laporan keuangan, yakni:

1. Dalam analisis, analis juga harus mengidentifikasi adanya trend-trend tertentu dalam laporan keuangan. Untuk itu laporan keuangan lima atau enam tahun barangkali bisa digunakan untuk melihat munculnya trend tertentu.

2. Angka-angka yang berdiri sendiri sulit dikatakan baik tidaknya. Untuk itu diperlukan pembanding yang bisa dipakai untuk melihat baik tidaknya angka yang dicapai oleh perusahaan. Rata-rata industri bisa dan biasa dipakai sebagai pembanding. Meskipun angka rata-rata industri ini barangkali bukan merupakan pembanding yang paling tepat karena beberapa hal seperti perbedaan karakteristik rata-rata perusahaan dalam industri dengan perusahaan tersebut.

3. Dalam analisis perusahaan, membaca dan menganalisis laporan keuangan dengan hati-hati adalah penting. Diskusi atau pernyataan yang melengkapi laporan keuangan seperti diskusi strategi perusahaan, diskusi rencana ekspansi atau restrukturisasi, merupakan bagian integral yang harus dimasukkan dalam analisis.

4. Analisis barangkali akan memerlukan informasi lain. Kadang kala semua informasi yang diperlukan bisa diperoleh melalui analisis mendalami laporan keuangan. Kadangkala informasi tambahan di luar laporan keuangan diperlukan. Informasi tambahan ini bisa memberi analisis yang lebih tajam lagi. Sebagai contoh analisis penurunan penjualan bila disertai dengan analisis perkembangan market share akan memberi pandangan baru kenapa penjualan bisa menurun (Irham, 2012)

Syafri (2001) menyatakan bahwa laporan keuangan yang baik dan akurat dapat menyediakan informasi yang berguna antara lain; 1) Pengambilan keputusan investasi, 2) keputusan pemberian kredit, 3) penilaian aliran kas, 4) penilaian sumbersumber ekonomi, 5) melakukan klaim terhadap sumber-sumber dana, 6) menganalisis perubahan-perubahan yang terjadi terhadap sumber-sumber dana , 7) menganalisis penggunaan dana

\section{Du Pont System}

Du Pont System dapat mencerminkan kinerja dari suatu perusahaan berdasarkan rasio yang ada di analisis Du Pont System yaitu rasio profitabilitas dan rasio aktivitas, sedangkan penilaian efektivitas suatu perusahaan dapat dilihat dengan 
cara menganalisis laporan keuangan suatu perusahaan yang berisikan data-data keuangan perusahaan (Sutrisno, 2003).

Du Pont System digunakan sebagai metode untuk menganalisis efektivitas perusahaan dengan analisis Du Pont System karena Du Pont System memungkinkan kita mengetahui faktor mana antara Net Profit Margin dan Total Asset Turnover, yang paling besar pengaruhnya terhadap Return On Investment. Du Pont System juga bermanfaaat untuk mengukur pengendalian biaya dan efektivitas penggunaan aktiva yang disebabkan oleh naik turunnya penjualan yang bisa kita ukur, sehingga kita bisa menentukan strategi penjualan di masa depan agar profitabilitas dari suatu perusahaan menaik (Dede, 2017).

Teknik Analisa yang digunakan penulis adalah menggunakan Du Pont System dalam menilai efektivitas perusahaan (Lukman, 2011). Indikator dalam Du Pont System untuk menilai efektivitas perusahaan adalah rasio profitabilitas dan rasio aktivitas yaitu: Return On Investment (ROI), Net Profin Margin (NPM), Total Assets Turnover (TATO). Berikut adalah cara perhitungan variable-variabel berikut:

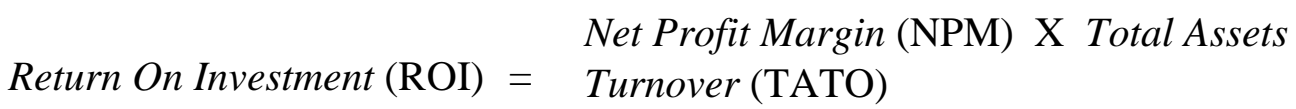

Net Profit Margin (NPM) $=\frac{\text { Penjualan Bersih }}{\text { Laba Bersih Setelah Pajak }} \times 100 \%$

Rasio aktivitas merupakan rasio yang terdapat dalam Du Pont System untuk menilai efektivitas perusahaan dalam penggunaan aktiva perusahaan. Adapun rasio yang digunakan adalah:

Total Assets Turnover (TATO) $=\frac{\text { Penjualan Bersih }}{\text { Total Aktiva }}$

\section{METODE PENELITIAN}

Dalam penelitian ini metode yang digunakan adalah metode deskriptif dengan pendekatan kuantitatif. Metode penelitian deskriptif dengan pendekatan kuantitatif yang dipergunakan dapat menggambarkan suatu kegiatan atau kejadian dengan menggunakan 
data berupa angka. Dalam penelitian ini data yang diambil adalah data sekunder, yaitu data yang diperoleh secara tidak langsung dari situs www.idx.co.id yaitu berupa laporan keuangan perusahaan PT. Gajah Tunggal Tbk. periode 2013 sampai dengan dan termasuk dalam studi kepustakaan atau mempelajari referensi jurnal-jurnal, buku-buku, peneliti harus menggunakan sumber aslinya dalam mengemukakan teori yang relevan dengan masalah yang akan dibahas.

\section{HASIL PENELITIAN}

Untuk menilai tingkat pegembalian investasi yang ada di perusahaan tersebut dapat dilakukan dengan membandingkan Analisis Du Pont System PT. Gajah Tunggal Tbk dengan perusahaan sejenis sehingga dapat diketahui tingkat pengembalian investasi perusahaan apabila dibandingkan dengan perusahaan lain yang sejenis. Perhitungan rata-rata standar industri perusahaan yang sejenis dengan PT. Gajah Tunggal Tbk yaitu perusahaan yang termasuk dalam sektor otomotif yang terdaftar pada Bursa Efek Indonesia.

Tabel 1

Hasil Perhitungan Total Assets Turnover

PT. Gajah Tunggal Tbk. Periode 2013-2017

\begin{tabular}{ccccc}
\hline Tahun & Penjualan & $\begin{array}{c}\text { Total } \\
\text { Aktiva }\end{array}$ & $\begin{array}{c}\text { Total Assets } \\
\text { Turnover }\end{array}$ & $\begin{array}{c}\text { Naik } \\
\text { (Turun) }\end{array}$ \\
\hline 2013 & 12.336 .150 & 14.780 .623 & 0,8 kali & - \\
\hline 2014 & 13.045 .379 & 16.116 .768 & 0,8 kali & 0 \\
\hline 2015 & 12.945 .478 & 17.500 .712 & 0,7 kali & $(0,1)$ \\
\hline 2016 & 13.606 .592 & 18.684 .709 & 0,7 kali & 0 \\
\hline 2017 & 14.108 .831 & 18.117 .527 & 0,8 kali & 0,1 \\
\hline
\end{tabular}

Sumber: Laporan Keuangan PT. Gajah Tunggal Tbk. Periode 2013-2017.

Tabel 2

Hasil Perhitungan Net Profit Margin PT. Gajah Tunggal Tbk. Periode 2013-2017

\begin{tabular}{ccccc}
\hline Tahun & $\begin{array}{c}\text { Laba Bersih } \\
\text { Setelah Pajak }\end{array}$ & Total Penjualan & $\begin{array}{c}\text { Net Profit } \\
\text { Margin }\end{array}$ & $\begin{array}{c}\text { Naik } \\
\text { (Turun) }\end{array}$ \\
\hline 2013 & 113.572 & 12.336 .150 & $1 \%$ & - \\
\hline 2014 & 332.218 & 13.045 .379 & $2,5 \%$ & $1,5 \%$ \\
\hline 2015 & $(313.326)$ & 12.945 .478 & $-2,4 \%$ & $(4,9 \%)$ \\
\hline 2016 & 626.561 & 13.606 .592 & $4,6 \%$ & $7 \%$ \\
\hline 2017 & 45.028 & 14.108 .831 & $0,3 \%$ & $(4,3 \%)$ \\
\hline Sumber: Laporan Keuangan PT. Gajah Tunggal Tbk. periode 2013-2017.
\end{tabular}


Tabel 3

Hasil Perhitungan Return On Investment

PT. Gajah Tunggal Tbk. Periode 2013-2017

\begin{tabular}{ccccc}
\hline Tahun & $\begin{array}{c}\text { Net Profit } \\
\text { Margin }\end{array}$ & $\begin{array}{c}\text { Total Assets } \\
\text { Turnover }\end{array}$ & $\begin{array}{c}\text { Return On } \\
\text { Investment }\end{array}$ & $\begin{array}{c}\text { Naik } \\
\text { (Turun) }\end{array}$ \\
\hline 2013 & $1 \%$ & $0,8 \mathrm{kali}$ & $0,8 \%$ & - \\
\hline 2014 & $2,5 \%$ & $0,8 \mathrm{kali}$ & $1,6 \%$ & $0,8 \%$ \\
\hline 2015 & $-2,4 \%$ & $0,7 \mathrm{kali}$ & $-1,7 \%$ & $(3,3 \%)$ \\
\hline 2016 & $4,6 \%$ & $0,7 \mathrm{kali}$ & $3,2 \%$ & $4,9 \%$ \\
\hline 2017 & $0,3 \%$ & $0,8 \mathrm{kali}$ & $0,2 \%$ & $(3 \%)$ \\
\hline
\end{tabular}

Sumber: Laporan Keuangan PT. Gajah Tunggal Tbk. periode 2013-2017.

Total Assets Turnover (TATO) pada tahun 2013 sebesar 0,8 kali sedangkan pada tahun 2014 Total Assets Turnover (TATO) sebesar 0,8 kali yang artinya tidak terjadi penurunan atau kenaikan sama sekali dibandingkan dengan Total Assets Turnover (TATO) sebelumnya. Total Assets Turnover (TATO) pada tahun 2015 sebesar 0,7 kali yang artinya terjadi penurunan Total Assets Turnover (TATO) sebesar 0,1 kali dari tahun sebelumnya, penurunan ini disebabkan oleh faktor penjualan yang menurun. Total Assets Turnover (TATO) pada tahun 2016 sebesar 0,7 kali yang artinya tidak terjadi penurunan atau kenaikan sama sekali dari tahun sebelumnya namun tetap masih belum ada kenaikan kembali dari pada tahun 2014. Total Assets Turnover (TATO) pada tahun 2017 adalah sebesar 0,8 kali yang artinya Total Assets Turnover (TATO) mengalami kenaikan sebesar 0,1 kali daripada tahun sebelumnya, hal itu di sebabkan kenaikan yang berarti pada penjualan.

Berdasarkan hasil perhitungan di atas meunjukan bahwa pada tahun 2013 bahwa Marjin Laba Bersih atau Net Profit Margin (NPM) yaitu menunjukan sebesar 1\%. Pada tahun 2014 Net Profit Margin (NPM) ada di angka 2,5\% yang artinya pada tahun 2014 Net Profit Margin mengalami kenaikan 1,5\% dari tahun sebelumnya. Pada tahun 2015 Marjin Laba Bersih atau Net Profit Margin (NPM) menunjukan di angka 2,4\% yang mana artinya bahwa pada tahun 2015 Net Profit Margin (NPM) mengalami penurunan $-4,9 \%$ bahkan menunjukan nilai negatif, hal itu disebabkan oleh turun nya nilai dari Laba Bersih Setelah Pajak yang bahkan bisa dibilang mengalami kerugia karena menunjukan nilai negatif. Pada tahun 2016 Marjin Laba Bersih atau Net Profit Margin (NPM) pad PT. Gajah Tunggal Tbk. kembali mengalami kebangkitan dengan hasil $4,6 \%$ yaitu naik sekitar $7 \%$ setelah sempat terpuruk di tahun sebelumnya yang mengalami hasil negatif, kenaikan ini disebabkan oleh meningkatnya laba bersih setelah pajak yang diiringi dengan kenaikan pada penjualan. Pada tahun 2017 Net Profit Margin (NPM) mengalami penurunan kembali ke angka $0,3 \%$ yang artinya mengalami penurunan 4,3\% dari tahun sebelumnya, hal ini disebabkan oleh hasil laba bersih setelah pajak yang rendah pada tahun tersebut.

Hasil perhitungan di atas menunjukan bahwa selama periode 2013-2017 tingkat pengembalian investasi atau Return On Investment (ROI) PT. Gajah Tunggal Tbk. mengalami fluktuasi. Return On Investment (ROI) pada tahun 2014 menunjukan 
tingkat pengembalian investasi yang baik jika dibandingkan dengan periode sebelumnya. Lalu Return On Investment (ROI) pada tahun 2015 menunjukan tingkat pengembalian investasi yang kurang baik atau cenderung buruk jika di bandingkan dengan periode yang sebelumnya. Selanjutnya Return On Investment (ROI) pada tahun 2016 kembali menunjukan tingkat pengembalian investasi yang baik dengan mengalami kenaikan dengan hasil ROI di angka 3,2\% atau naik sekitar 4,9\% dari periode sebelumnya. Lalu Return On Investment (ROI) pada tahun 2017 cenderung mengalami tingkat pengembalian investasi yang kurang baik kembali dari periode sebelumnya dengan mengalami penurunan di angka 0,2\%. Angka Tingkat pengembalian Investasi atau Return On Investment (ROI) yang menunjukan tingkat pengembalian yang baik ditunjukan pada tahun 2014 dan 2016 karena angka tingkat pengembalian investasi pad tahun tersebut menunjukan peningkatan daripada tingkat pengembalian investasi periode sebelumnya. Berikut ini adalah perbandingan hasil perhitungan Total Assets Turnover, Net Profit Margin dan, Return On Investment PT. Gajah Tunggal Tbk. dengan rata-rata standar indsutri periode 2013-2017:

Tabel 4

Perbandingan Hasil Perhitungan Total Assets Turnover PT. Gajah Tugal Tbk. Periode 2013 -2017 dengan Rata-rata Industri

\begin{tabular}{cccc}
\hline Tahun & $\begin{array}{c}\text { Total Assets } \\
\text { Turnover }\end{array}$ & Standar Industri & Keterangan \\
\hline 2013 & $0,8 \mathrm{kali}$ & $0,9 \mathrm{kali}$ & Tidak Baik \\
\hline 2014 & $0,8 \mathrm{kali}$ & $0,8 \mathrm{kali}$ & Baik \\
\hline 2015 & $0,7 \mathrm{kali}$ & $0,7 \mathrm{kali}$ & Baik \\
\hline 2016 & $0,7 \mathrm{kali}$ & $0,7 \mathrm{kali}$ & Baik \\
\hline 2017 & $0,8 \mathrm{kali}$ & $0,7 \mathrm{kali}$ & Baik \\
\hline
\end{tabular}

Sumber: Laporan Keuangan PT. Gajah Tunggal Tbk. Periode 2013-2017.

Tabel 5

Perbandingan Hasil Perhitungan Net Profit Margin PT. Gajah Tugal Tbk. Periode 2013 -2017 dengan Rata-rata Industri

\begin{tabular}{cccc}
\hline Tahun & Net Profit Margin & Standar Industri & Keterangan \\
\hline 2013 & $1 \%$ & $6,1 \%$ & Tidak Baik \\
\hline 2014 & $2,5 \%$ & $4,5 \%$ & Tidak Baik \\
\hline 2015 & $-2,4 \%$ & $0,1 \%$ & Tidak Baik \\
\hline 2016 & $4,6 \%$ & $0,5 \%$ & Baik \\
\hline 2017 & $0,3 \%$ & $19,4 \%$ & Tidak Baik \\
\hline
\end{tabular}

Sumber: Laporan Keuangan PT. Gajah Tunggal Tbk. Periode 2013-2017. 
Tabel 6

Perbandingan Hasil Perhitungan Return On Investment

PT. Gajah Tugal Tbk. Periode 2013 -2017 dengan Rata-rata Industri

\begin{tabular}{cccc}
\hline Tahun & $\begin{array}{c}\text { Return On } \\
\text { Investment }\end{array}$ & Standar Industri & Keterangan \\
\hline 2013 & $0,8 \%$ & $5,5 \%$ & Tidak Baik \\
\hline 2014 & $1,6 \%$ & $4,7 \%$ & Tidak Baik \\
\hline 2015 & $-1,7 \%$ & $0,1 \%$ & Tidak Baik \\
\hline 2016 & $3,2 \%$ & $0,4 \%$ & Baik \\
\hline 2017 & $0,2 \%$ & $10,3 \%$ & Tidak Baik \\
\hline
\end{tabular}

Sumber: Laporan Keuangan PT. Gajah Tunggal Tbk. Periode 2013-2017.

Tabel 7

Perbandingan Hasil Perhitungan Du Pont System

PT. Gajah Tugal Tbk. Periode 2013 -2017 dengan Rata-rata Industri

\begin{tabular}{ccccc}
\hline No. & Jenis Du Pont System & $\begin{array}{c}\text { Du Pont } \\
\text { System }\end{array}$ & $\begin{array}{c}\text { Standar } \\
\text { Industri } \\
\text { Otomotif }\end{array}$ & $\begin{array}{c}\text { Kriteria } \\
\text { (Baik/Tidak Baik) }\end{array}$ \\
\hline 1. & Total Assets Turnover & $0,8 \mathrm{kali}$ & $0,8 \mathrm{kali}$ & Baik \\
\hline 2. & Net profit Margin & $1,2 \%$ & $6,1 \%$ & Tidak Baik \\
\hline 3. & Return On Investment & $0,8 \%$ & $4,2 \%$ & Tidak Baik \\
\hline
\end{tabular}

Sumber: diolah penulis, 2019.

\section{PEMBAHASAN}

Berdasarkan data di atas, Total Assets Turnover pada tahun 2013 sebesar 0,8 kali jika dibandingkan dengan standar industri Total Assets Turnover tahun 2013 sebesar 0,9 kali dinilai tidak baik karena berada di bawah rata-rata industri perusahaan sejenis. Pada tahun 2014 Total Assets Turnover sebesar 0,8 kali jika dibandingkan dengan standar industri Total Assets Turnover tahun 2014 sebesar 0,8 kali dinilai baik karena berada setara dengan rata-rata industri perusahaan sejenis. Pada tahun 2015 Total Assets Turnover sebesar 0,7 kali jika dibandingkan dengan standar industri Total Assets Turnover tahun 2015 sebesar 0,7 kali dinilai baik karena berada setara dengan rata-rata industri perusahaan sejenis. Pada tahun 2016 Total Assets Turnover sebesar 0,8 kali jika dibandingkan dengan standar industri Total Assets Turnover tahun 2016 sebesar 0,8 kali dinilai baik karena berada setara dengan rata-rata industri perusahaan sejenis. Pada tahun 2017 Total Assets Turnover sebesar 0,8 kali jika dibandingkan dengan standar industri Total Assets Turnover tahun 2017 sebesar 0,7 kali dinilai baik karena berada di atas dari rata-rata industri perusahaan sejenis.

Berdasarkan data di atas, Net Profit Margin pada tahun 2013 sebesar 1\% jika dibandingkan dengan standar industri Net Profit Margin tahun 2013 yaitu sebesar 6,1\% dinilai tidak baik karena berada di bawah rata-rata industri perusahaan sejenis. Pada tahun 2014 Net Profit Margin sebesar 2,5\% jika dibandingkan dengan standar industri Net Profit Margin tahun 2014 yaitu sebesar 4,5\% dinilai tidak baik karena berada di bawah rata-rata industri perusahaan yang sejenis. Pada tahun 2015 Net Profit Margin sebesar -2,5\% jika dibandingkan dengan standar industri Net Profit Margin tahun 2015 
yaitu sebesar $0,1 \%$ dinilai tidak baik karena berada di bawah rata-rata industri perusahaan yang sejenis bahkan mengalami nilai negatif. Pada tahun 2016 Net Profit Margin sebesar 4,6\% jika dibandingkan dengan standar industri Net Profit Margin tahun 2016 yaitu sebesar $0,5 \%$ dinilai baik karena berada di atas rata-rata industri perusahaan yang sejenis. Pada tahun 2017 Net Profit Margin sebesar 0,3\% jika dibandingkan dengan standar industri Net Profit Margin tahun 2017 yaitu sebesar $19,4 \%$ dinilai tidak baik karena berada di bawah rata-rata industri perusahaan yang sejenis.

Berdasarkan data di atas, Return On Investment pada tahun 2013 sebesar 0,8\% jika dibandingkan dengan standar industri Return On Investment tahun 2013 sebesar 5,5\% dinilai tidak baik karena berada di bawah rata-rata industri perusahaan sejenis. Pada tahun 2014 Return On Investment sebesar 1,6\% jika dibandingkan dengan standar industri Return On Investment 2014 yaitu sebesar 4,7\% dinilai tidak baik karena berada di bawah rata-rata industri perusahaan sejenis. Pada tahun 2015 Return On Investment sebesar $-1,7 \%$ jika dibandingkan dengan standar industri Return On Investment 2015 yaitu sebesar $0,1 \%$ dinilai tidak baik dan bahkan dinilai buruk karena bernilai negatif lalu dikarenakan berada di bawah rata-rata industri perusahaan sejenis. Pada tahun 2016 Return On Investment sebesar 3,2\% jika dibandingkan dengan standar industri Return On Investment 2016 yaitu sebesar 0,4\% dinilai baik karena berada di atas rata-rata industri perusahaan sejenis. Pada tahun 2017 Return On Investment sebesar 0,2\% jika dibandingkan dengan standar industri Return On Investment 2017 yaitu sebesar 10,3\% dinilai tidak baik karena berada di bawah rata-rata industri perusahaan sejenis.

Berdasarkan tabel diatas Du Pont System pada PT. Gajah Tunggal Tbk. Periode 2013-2017 dengan membadingkan dengan standar industri otomotif yang terdaftar di Bursa Efek Indonesia bahwa Total Assets Turnover dalam kriteria yang baik karena perputaran total aset berputar 0,8 kali per lima tahun hal ini senada dengan indsutri sejenis yang berputar 0,8 kali per lima tahun. Untuk nilai dari Net Profit Margin berada dalam kriteria yang tidak baik karena tingkat laba yang dihasilkan atas penjualan hanya berkisar $1,2 \%$ per lima tahun sedangkan industri sejenis menghasilkan tingkat laba atas penjualan sebesar 6,1\% per lima tahun. Dan yang terakhir untuk Return On Investment nya dalam kriteria tidak baik karena hanya menghasilkan tingkat pengembalian investasi sebesar $0,8 \%$ sedangkan tingkat pengembalian dari industri sejenis yaitu sebesar $4,2 \%$.

\section{SIMPULAN}

Berdasarkan hasil penelitian yang telah dilakukan mengenai efektivitas perusahaan yang ditinjau dari tingkat pengembalian investasi pada PT. Gajah Tunggal Tbk. selama kurun waktu lima tahun yaitu tahun 2013 sampai dengan tahun 2017 dapat disimpulkan bahwa efektivitas perusahaan selama lima tahun tersebut dinilai kurang baik melihat penurunan yang terjadi pada beberapa aspek yang di teliti dapat mempengaruhi nilai akhir Du Pont System, dimulai dari Net Profit Margin yang 
mengalami fluktuasi dengan dua kali penurunan yaitu pada tahun 2015 dan pada tahun 2017, hal itu disebabkan oleh tingkat laba bersih setelah pajak yang dihasilkan mengalami kerugian atau tingkat laba bersih setelah pajak nya bernilai rendah. Walaupun dari segi Perputaran Total Aset atau Total Assets Turnover bisa dinilai cukup efektif karena hanya mengalami sekali penurunan yaitu penurunan pada tahun 2015 yang karena disebabkan oleh tingkat penjualan tidak seimbang dengan tingkat jumlah aktiva sehingga tingkat penjualan berdasarkan aset tetap mengalami penurunan. Lalu yang terakhir Return On Investment dari perusahaan selama lima tahun periode yang ditetapkan dinilai kurang efektif hal ini di karenakan Return On Investment pada perusahaan mengalami fluktuasi dengan dua kali naik dan dua kali mengalami penurunan yaitu pada tahun 2015 yang disebabkan oleh tingkat Net Profit Margin yang rendah bahkan negatif yang disebabkan juga oleh tingkat laba bersih setelah pajak yang rendah.

\section{DAFTAR PUSTAKA}

David, L. (2013) Penilaian Kinerja Keuangan Perusahaan Menggunakan Analisis Du Pont. Universitas Ma Chung Jurnal JIBEKA, 7 (2) : $25-31$

Fahmi, I. (2012). Analisis Laporan Keuangan. Cetakan Ke-2. Bandung: Alfabeta.

Harahap, S.,S. (2001). Analisis Kritis Atas Laporan Keuangan. Cetakan Ketiga. Jakarta: PT Raja Grafindo Persada.

Irmaningsih, D. (2017). Analisis Penerapan Du Pont System untuk Mengukur Kinerja Keuangan Perusahaan (Studi Pada Sub Sektor Perusahaan Makanan dan Minuman yang Terdaftar di Bursa Efek Indonesia Periode Tahun 2012-2015). Universitas Lampung.

Kasmir. (2012), Analisis Laporan Keuangan. Jakarta : PT. Raja Grafindo Persada.

Sutrisno, (2003), Manajemen Keuangan (Teori, Konsep, dan Aplikasi), Edisi Pertama, Cetakan Kedua. Yogyakarta: EKONISIA.

Syamsuddin, Lukman. (2011). Manajemen Keuangan Perusahaan. Jakarta: Rajawali Pers. 